\title{
Effect of temperature on predation by Harmonia axyridis (Pall.) (Coleoptera: Coccinellidae) on the walnut aphids Chromaphis juglandicola Kalt. and Panaphis juglandis (Goeze)
}

\author{
Guizhen Gao', Siqi Liu', Likai Feng², Yuli Wang ${ }^{1}$ and Zhaozhi Lu ${ }^{3 *}$
}

\begin{abstract}
Background: The walnut aphid species Chromaphis juglandicola Kalt. and Panaphis juglandis (Goeze) are destructive insect pests. Harmonia axyridis (Pall.) (Coleoptera: Coccinellidae) is the main predatory insect with a wide geographical distribution. The feeding behavior of the predator against the two different aphid species might influence bio-control efficacy in walnut orchards.

Main body: Functional response of $\mathrm{H}$. axyridis to various densities of the two aphid species was examined under temperatures ranging from 15 to $30^{\circ} \mathrm{C}$. The results showed that functional responses of $H$. axyridis towards $C$. juglandicola or $P$. juglandis fitted well with the Holling-ll equation within the range of $15-30{ }^{\circ} \mathrm{C}$. A greater biomass of aphids was consumed when the temperature increased from 15 to $30^{\circ} \mathrm{C}$. The predation efficacy of $\mathrm{H}$. axyridis against $C$. juglandicola was greater than against $P$. juglandis, and the searching efficiency of $H$. axyridis against $C$. juglandicola was more effective than against $P$. juglandis. Moreover, predation rates against both aphid species decreased with increasing the $H$. axyridis density.

Conclusion: This study showed that $H$. axyridis was an effective predator against the two walnut aphids. Increasing temperature $\left(15-30^{\circ} \mathrm{C}\right)$ increased prey consumption. Interference between individuals from increasing predator density had a negative impact on predation rate against the two aphid species.
\end{abstract}

Keywords: Walnut aphid, Biological control, Functional response, Temperature, Predator interference

\section{Background}

The small walnut aphid, Chromaphis juglandicola Kaltenbach and the large walnut aphid, Panaphis juglandis Goeze (Hemiptera: Aphididae), are distributed mainly in temperate regions and are destructive pests in walnut orchards in Xinjiang Uygur Autonomous Region, northwestern China (Xing et al. 2018). Chromaphis juglandicola lives on the undersides of the leaves of walnut trees.

\footnotetext{
* Correspondence: zhaozhi_Iv@sina.com

${ }^{3}$ College of Plant Health and Medicine, Qingdao Agricultural University, Qingdao 266109, China

Full list of author information is available at the end of the article
}

Panaphis juglandis typically feeds along the midrib of the upper surface of the leaves. These two species are not usually found together on the same tree in the Kashmir valley, India (Wani and Ahmad 2014a, b), while both species commonly coexist at the same orchard in the Yili River Valley in Xinjiang Uygur Autonomous Region (Xing et al. 2018).

Coccinellids (lady beetles) are the most important and dominant predatory species regulating populations of the walnut aphid C. juglandicola (Sluss 1967). Harmonia axyridis Pallas (Coleoptera: Coccinellidae) is the main Coccinellid species that feeds on walnut aphids in Yili

\section{Springer Open}

() The Author(s). 2020 Open Access This article is licensed under a Creative Commons Attribution 4.0 International License, which permits use, sharing, adaptation, distribution and reproduction in any medium or format, as long as you give appropriate credit to the original author(s) and the source, provide a link to the Creative Commons licence, and indicate if changes were made. The images or other third party material in this article are included in the article's Creative Commons licence, unless indicated otherwise in a credit line to the material. If material is not included in the article's Creative Commons licence and your intended use is not permitted by statutory regulation or exceeds the permitted use, you will need to obtain permission directly from the copyright holder. To view a copy of this licence, visit http://creativecommons.org/licenses/by/4.0/. 
River Valley (Xing et al. 2018). Harmonia axyridis was introduced to North America (Gordon 1985) and Europe (Katsoyannos et al. 1997, Iperti and Bertand 2001) as a biological control agent. Knowledge about the capacity of a predator to kill target prey is essential to developing comprehensive strategies for its release as a biological control agent (Symondson et al. 2002).

Temperature is one of the main abiotic factors influencing the potential of natural enemies to suppress pests (Zamani et al. 2006; Sarnevesht et al. 2018; Su et al. 2018; Lin et al. 2019, Luhring et al. 2019), but its effects may differ between different predator species. Little is known about the functional response of $H$. axyridis towards the two walnut aphid species above at different temperatures, although this information is requisite to establishing an effective biological control strategy using $H$. axyridis. The walnut aphids are becoming a more serious problem as the development of walnut orchards intensifies in China. The objective of this study was to determine the effect of temperature on the functional response of $H$. axyridis against $C$. juglandicola and $P$. juglandis of different densities and at different temperatures.

\section{Materials and methods}

\section{Sources of $H$. axyridis, $C$. juglandicola, and $P$. juglandis}

The adult lady beetles of $H$. axyridis and the two aphid species, C. juglandicola and P. juglandis, used in this study were collected from fresh leaves of walnut trees in Yili(N4314' $53^{\prime \prime}$, E82 $\left.49^{\prime} 40^{\prime \prime}\right)$, Xinjiang, China. Aphid colonies were maintained on young walnut plants in a controlled-climate room held at $25 \pm 1{ }^{\circ} \mathrm{C}, 60 \pm 10 \%$ $\mathrm{RH}$, and under a photoperiod of 14:10 h (L:D).

Functional response: predation by $H$. axyridis on aphids at various densities and four temperatures

The functional response (number of aphids consumed per day) of $H$. axyridis was determined by offering varying densities of 2nd/3rd instar nymphs of each aphid species separately on a walnut leaf disc placed in a Petri dish $(90 \mathrm{~mm}$ by $18 \mathrm{~mm}$ ) lined on the base with moist filter paper. Prey densities were 80, 160, 240, 320, 400, and 600 aphid nymphs of $C$. juglandicola and 60, 120, 180, 240, 300, 360 aphid nymphs of $P$. juglandis. After adding the prey, one adult of $H$. axyridis, starved for $24 \mathrm{~h}$, was added to and confined in the Petri dish. The Petri dishes were kept in environmental chambers under four different constant temperatures: $15,20,25$, and $30 \pm 1{ }^{\circ} \mathrm{C}$, with $60 \pm 10 \% \mathrm{RH}$ and a light: dark photoperiod of 14 : $10 \mathrm{~h}$. The number of aphids consumed by the $H$. axyridis was recorded after $24 \mathrm{~h}$. Each aphid density and aphid species was replicated six times for each temperature, simultaneously.
Intraspecies interference within $H$. axyridis whilst feeding on aphids

To test how intraspecific interference affected predation by $H$. axyridis on walnut aphids, one, two, three, four, or five adult(s) of $H$. axyridis lady beetles were starved for $24 \mathrm{~h}$ and then added to Petri dishes (as above) containing 600 2nd/3rd instar nymphs of each aphid species separately. The number of aphids consumed was recorded after $24 \mathrm{~h}$. Experiments were conducted under $25 \pm 1{ }^{\circ} \mathrm{C}, 60 \pm 10 \% \mathrm{RH}$ and a photoperiod of $14: 10 \mathrm{~h}$ (L:D). Six replicate experiments using each $H$. axyridis density were undertaken.

\section{Data analysis}

The Holling's type II equation (Holling 1959, 2003) was used to model the functional response of $H$. axyridis preying on aphids:

$$
N_{a}=a T N_{0} /\left(1+a T_{h} N_{0}\right)
$$

where $N_{a}$ is the number of aphids consumed per day and $N_{o}$ is the initial number of prey (aphids); $T_{h}$ is the handling time of $H$. axyridis preying on aphids, $a$ is the successful attack rate, and $T$ is the time of the experiment, which in this case was one day.

The values of $a$ and $T_{h}$ were found by linearly regressing $1 / N_{a}$ against $1 / N_{0}$. The resultant $y$-intercept is the initial estimate of $T_{h}$ and the reciprocal of the regression coefficient (slope) is an estimate of $a$ (Livdahl and Stiven 1983). We used equation (1) $N_{a}=a T N_{o} /\left(1+a T_{h} N_{o}\right)$, when $N_{O}$ was infinitely great. The equation, $N_{a} / N_{O}=T /$ $T_{h}$, estimated maximum predation number.

The searching efficiency was calculated as

$$
S=a /\left(1+a T_{h} N\right)
$$

where $S$ is searching efficiency, $a$ is the successful attack rate, $T_{h}$ is the handling time and $N$ is the number of prey.

The average predation rate was calculated using Watt's (1959) equation:

$$
A=Q P^{-m}
$$

where $A$ is the average predation rate, $P$ is predator density of $1,2,3,4$, or $5 \mathrm{H}$. axyridis adults, $m$ is the coefficient of interference, and $Q$ is the seeking constant. The values of $Q$ and $m$ were found by powerexponential regressing $\mathrm{A}$ and $\mathrm{P}$.

Model fitting was performed using Origin version 7.5 for Windows.

\section{Results and discussion}

The functional response of $H$. axyridis lady beetles preying on C. juglandicola and P. juglandis was described well by the Holling's type II equation within the range of 
$15-30^{\circ} \mathrm{C}$ (Fig. 1). The number of aphids consumed daily by $H$. axyridis increased gradually until reaching the upper asymptote of 219, 239, 256, 278 aphids/ predator for C. juglandicola and 99, 129, 156, 177 aphids/predator for $P$. juglandis at 15, 20, 25, and $30^{\circ} \mathrm{C}$, respectively (Fig. 1). This result is in accordance with the results of Lee and Kang (2004), Atlihan et al. (2010) and Islam et al. (2020).

The predation of $H$. axyridis on $C$. juglandicola and $P$. juglandis was different within the range of $15-30{ }^{\circ} \mathrm{C}$ (Fig. 1 and Table 1). The attacking efficiency of $H$. axyridis was 0.7944 to 1.0862 on C. juglandicola and 0.5798 to 0.8468 on $P$. juglandis within the range of $15-30{ }^{\circ} \mathrm{C}$. The predation capacity $\left(a / T_{h}\right)$ and the maximum daily predation $\left(1 / T_{h}\right)$ of $H$. axyridis on $C$. juglandicola was higher than on $P$. juglandis. Moreover, the handling time $\left(T_{h}\right)$ of $H$. axyridis was 0.0031 to 0.0019 days on $C$. juglandicola and 0.0075 to 0.0029 days on P. juglandis within the range of $15-30{ }^{\circ} \mathrm{C}$. This might be because the body size of $P$. juglandis is larger than $C$. juglandicola, and $H$. axyridis need much more time to handle and digest accordingly.

Temperature significantly influenced the predation capacity of $H$. axyridis to walnut aphids (Fig. 1 and Table 1 ). The predation capacity of $H$. axyridis and the maximum daily number of walnut aphids eaten (predation number) increased as the temperature increased from 15 to $30{ }^{\circ} \mathrm{C}$. This agrees with the finding of Schwarz and Frank (2019) that $H$. axyridis, as well as three other lady beetle species, consumed more aphid biomass under increasing temperatures. Hong et al. (2013) also found that the predation capacity of
Micraspis discolor Fabricius (Coleoptera: Coccinellidae) feeding on Brevicoryne brassicae L. (Hemiptera: Aphididae) was higher at $30.7{ }^{\circ} \mathrm{C}$ than at $23.5{ }^{\circ} \mathrm{C}$. The handling time by $H$. axyridis of walnut aphids was shortened as the temperature increased, which is in accordance with the finding of Jalali et al. (2010) who reported that the handling time of Adalia bipunctata L. (Coleoptera: Coccinellidae) to Myzus persicae Sulzer (Hemiptera: Aphididae) significantly decreased as the temperature increased from 19 to $27^{\circ} \mathrm{C}$.

The searching efficiency $(S)$ by $H$. axyridis for walnut aphids decreased as the prey density increased within the range of $15-30^{\circ} \mathrm{C}$, and increased as the temperature increased from 15 to $30{ }^{\circ} \mathrm{C}$ (Fig. 2). Harmonia axyridis spent more time undertaking non-searching activities at low temperatures $\left(15^{\circ} \mathrm{C}\right)$, whereas more time searching occurred at higher temperatures. This may be attributed to temperature-related changes in the metabolism and activity of the predator (McCoull et al. 1998). The searching efficiency by $H$. axyridis for $C$. juglandicola was higher than for $P$. juglandis under each temperature regime. Chromaphis juglandicola and $P$. juglandis live on the undersides and the upper surface of the leaves in the field, respectively. Feng et al. (2018) found that prey distribution could affect $H$. axyridis foraging under relative high prey densities. Spatial heterogeneity also play a role in predator-prey systems (Hauzy et al. 2010). The small size of arenas used in laboratory predation experiments may be not representative of the natural searching efficiency of a predator (Murdoch, 1983). Nevertheless, our study has value as a first step in evaluating $H$. axyridis as a biological control agent of walnut aphids.

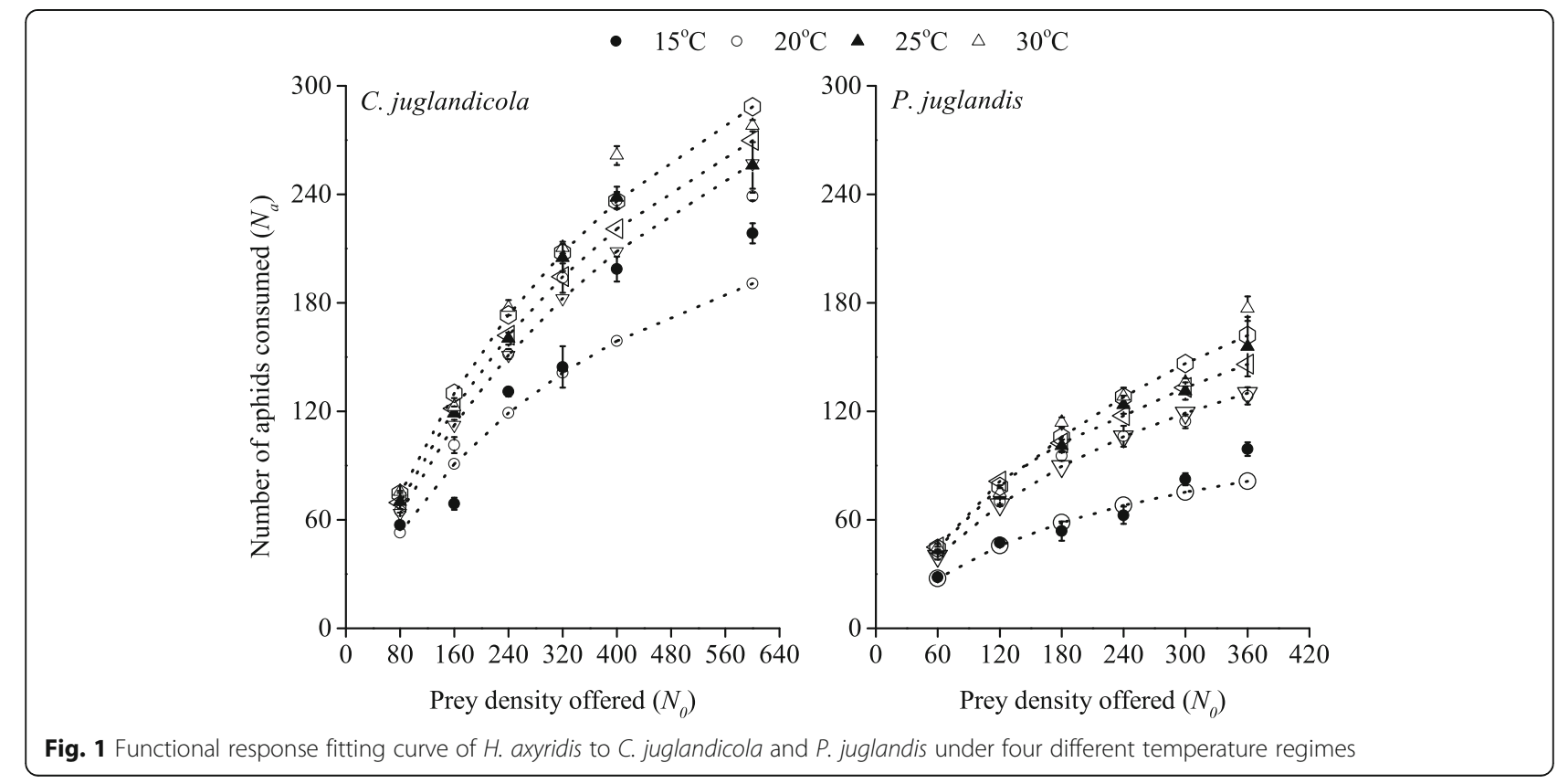


Table 1 Functional response of $H$. axyridis on C. juglandicola and $P$. juglandis under four different temperature regimes

\begin{tabular}{|c|c|c|c|c|c|c|c|}
\hline Aphids & $\begin{array}{l}\text { Temp. } \\
\left({ }^{\circ} \mathrm{C}\right)\end{array}$ & $\begin{array}{l}\text { Attacking } \\
\text { efficiency }(a)\end{array}$ & $\begin{array}{l}\text { Handling time } \\
T_{h}(d)\end{array}$ & $\begin{array}{l}\text { Predation capacity } \\
a / T_{h}\end{array}$ & $\begin{array}{l}\text { Maximum predation } \\
\text { number } 1 / T_{h}\end{array}$ & $\begin{array}{l}\text { Holling's type II } \\
\text { equation }\end{array}$ & $R^{2}$ \\
\hline \multirow[t]{4}{*}{$\begin{array}{l}\text { C. } \\
\text { juglandicola }\end{array}$} & 15 & 0.7944 & 0.0031 & 256.2604 & 322.5806 & $\begin{array}{l}\mathrm{Na}=0.7944 \mathrm{~N} /(1+ \\
0.0025 \mathrm{~N})\end{array}$ & 0.8756 \\
\hline & 20 & 0.9169 & 0.0021 & 434.5543 & 473.9336 & $\begin{array}{l}\mathrm{Na}=0.9169 \mathrm{~N} /(1+ \\
0.0019 \mathrm{~N})\end{array}$ & 0.9821 \\
\hline & 25 & 1.0158 & 0.0020 & 495.5050 & 487.8049 & $\begin{array}{l}\mathrm{Na}=1.0158 \mathrm{~N} /(1+ \\
0.0021 \mathrm{~N})\end{array}$ & 0.9964 \\
\hline & 30 & 1.0862 & 0.0019 & 565.7481 & 520.8333 & $\begin{array}{l}\mathrm{Na}=1.0862 \mathrm{~N} /(1+ \\
0.0021 \mathrm{~N})\end{array}$ & 0.9923 \\
\hline \multirow[t]{4}{*}{ P. juglandis } & 15 & 0.5798 & 0.0075 & 77.2065 & 133.1558 & $\begin{array}{l}\mathrm{Na}=0.5798 \mathrm{~N} /(1+ \\
0.0044 \mathrm{~N})\end{array}$ & 0.9641 \\
\hline & 20 & 0.8034 & 0.0042 & 189.4811 & 235.8491 & $\begin{array}{l}\mathrm{Na}=0.8034 \mathrm{~N} /(1+ \\
0.0034 \mathrm{~N})\end{array}$ & 0.9969 \\
\hline & 25 & 0.8386 & 0.0035 & 236.8973 & 282.4859 & $\begin{array}{l}\mathrm{Na}=0.8386 \mathrm{~N} /(1+ \\
0.0030 \mathrm{~N})\end{array}$ & 0.9978 \\
\hline & 30 & 0.8468 & 0.0029 & 293.0194 & 346.0208 & $\begin{array}{l}\mathrm{Na}=0.8468 \mathrm{~N} /(1+ \\
0.0024 \mathrm{~N})\end{array}$ & 0.9923 \\
\hline
\end{tabular}

The rates of predation by $H$. axyridis on $C$. juglandicola were 42.7, 28.7, 19.4, 17.5, and 17.0\%; and on P. juglandis $24.9,22.5,18.6,17.5$, and $14.8 \%$ at the predator densities of one, two, three, four and five, respectively. These results indicated intraspecific interference and a negative impact on predation when more than one predator was present (Fig. 3). Feng et al. (2019) found that interference between $H$. axyridis conspecifics might alter their foraging patterns. The coefficient of predator interference was 0.6124 when feeding on C. juglandicola, and 0.3134 when feeding on $P$. juglandis, which showed that interference between predators had a greater negative effect against $C$. juglandicola than against $P$. juglandis. This might be because $C$. juglandicola is more mobile than P. juglandis.

\section{Conclusion}

This study showed the potential of using $H$. axyridis lady beetles as biological control agents against two walnut aphid species, C. juglandicola and P. juglandis, under temperatures of $15-30{ }^{\circ} \mathrm{C}$. Further studies to determine the effect of inter- and intraspecies interference of predatory species should be conducted in the field.

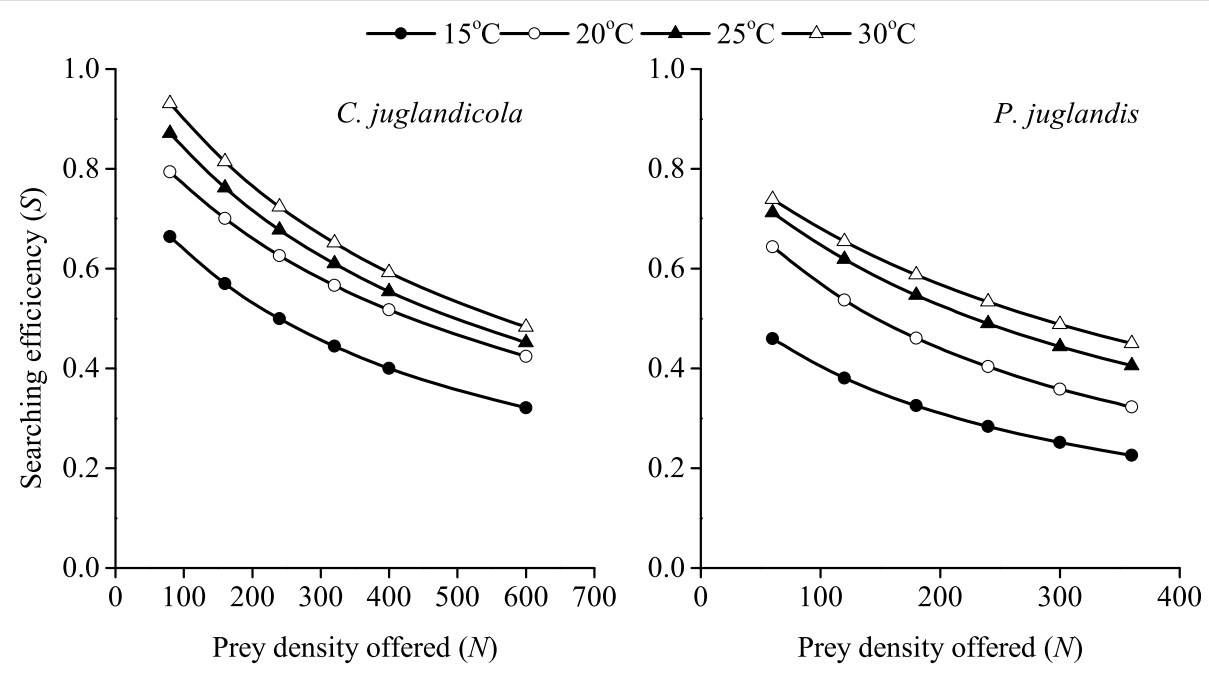

Fig. 2 Searching efficiency by $H$. axyridis of two walnut aphid species C. juglandicola and $P$. juglandis under four different temperature regimes 

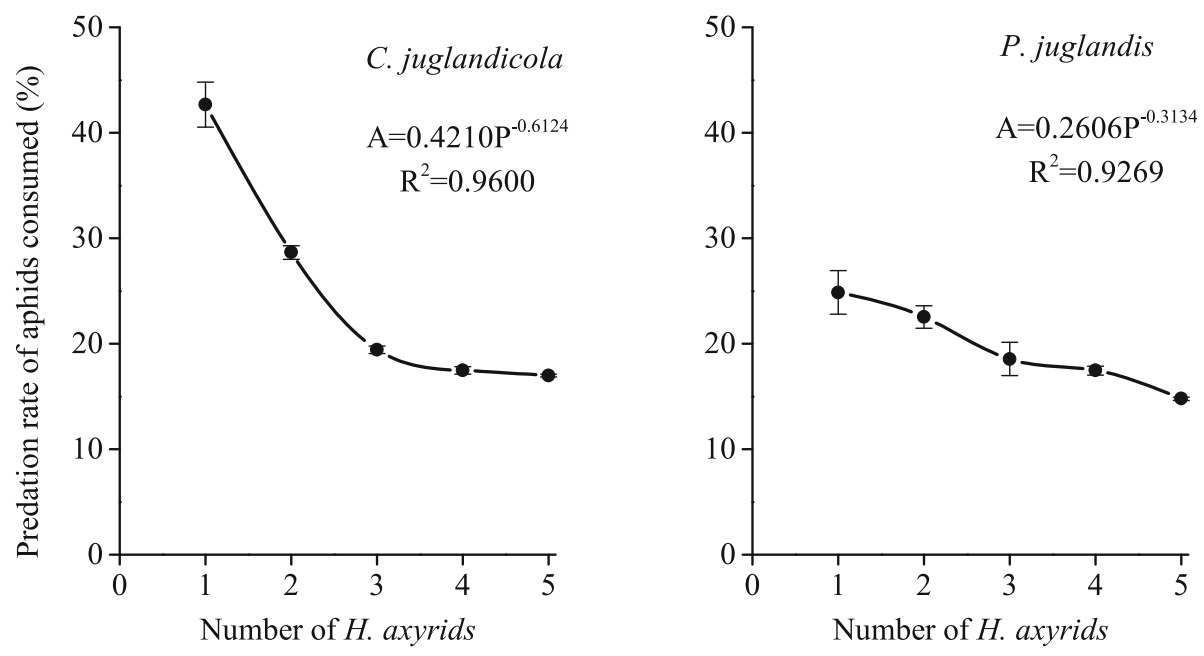

Fig. 3 Watt equation fitted curve of adult H. axyridis predation on C. juglandicola and P. juglandis

\section{Acknowledgements}

The authors are grateful to Qiang Wang and Naijin Wang for their technical assistance.

\section{Authors' contributions}

GZG and ZZL conceived and designed the experiments. SQL and YLW performed the experiments. GZG and SQL analyzed the data. GZG and ZZL wrote the manuscript main text. LKF and ZZL revised the manuscript. All authors approved the manuscript for submission.

\section{Funding}

The work was supported by the National Natural Science Foundation of China (31670656, 31960317), and the Xinjiang Uygur Autonomous Region Talent Project.

\section{Availability of data and materials}

The datasets used and/or analyzed during the current study are available from the corresponding author on reasonable request.

\section{Ethics approval and consent to participate}

Not applicable.

\section{Consent for publication}

Not applicable.

\section{Competing interests}

The authors declare that they have no competing interests.

\section{Author details}

${ }^{1}$ College of Forestry and Horticulture, Xinjiang Agricultural University, Urumqi 830052, China. ${ }^{2}$ Institute of Plant Protection, Xinjiang Academy of Agricultura and Reclamation Science, Shihezi 832000, China. ${ }^{3}$ College of Plant Health and Medicine, Qingdao Agricultural University, Qingdao 266109, China.

\section{Received: 6 April 2020 Accepted: 6 November 2020}

Published online: 17 November 2020

\section{References}

Atlihan R, Kaydan MB, Yarımbatman A, Okut H (2010) Functional response of the coccinellid predator Adalia fasciatopunctata revelierei to walnut aphid (Callaphis juglandis). Phytoparasitica 38:23-29

Feng Y, Li YD, Liu ZG, Yu XL, Zhu GX, Keller M, Liu TX (2019) Behavioral patterns and functional responses of a generalist predator revealed using automated video tracking. Pest Manag Sci 75:1517-1526
Feng Y, Zhou ZX, Ana MR, Yua XL, Liu TX (2018) The effects of prey distribution and digestion on functional response of Harmonia axyridis (Coleoptera: Coccinellidae). Biol Control 124:74-81

Gordon RD (1985) The Coleoptera (Coccinellidae) of America north of Mexico. J New York Entomol S 93:1-912

Hauzy C, Tully T, Spataro T, Paul G, Arditi R (2010) Spatial heterogeneity and functional response: an experiment in microcosms with varying obstacle densities. Oecologia 163:625-636

Holling CS (1959) The components of predation as revealed by a study of small mammal predatory of the European pine sawfly. Can Entomol 91:385-398

Holling CS (2003) Principles of insect predation. Annu Rev Entomol 6:163-182

Hong BM, Binh TTT, Hang VTT (2013) Effect of temperature on the life cycle and predatory capacity of ladybird beetle Micraspis discolor Fabricius (coleoptera: Coccinellidae). Tap Chí Sinh Học 35(1):37-42

Iperti G, Bertand E (2001) Hibernation of Harmonia axyridis (Coleoptera: Coccinellidae) in South-Eastern France. Acta Soc Zool Bohem 65:207-210

Islam Y, Shah FM, Shah MA, Khan MM, Rasheed MA, Rehman SU, Ali S, Zhou XM (2020) Temperature-dependent functional response of Harmonia axyridis (Coleoptera: Coccinellidae) on the eggs of Spodoptera litura (Lepidoptera: Noctuidae) in laboratory. Insects 11:583

Jalali MA, Tirry L, De Clercq P (2010) Effect of temperature on the functional response of Adalia bipunctata to Myzus persicae. BioControl 55:261-269

Katsoyannos P, Kontodimas DC, Stathas GJ, Tsartsalis CT (1997) Establishment of Harmonia axyridis on citrus and some data on its phenology in Greece. Phytoparasitica 25:183-191

Lee JH, Kang TJ (2004) Functional response of Harmonia axyridis (Pallas) (Coleoptera: Coccinellidae) to Aphis gossypii Glover (Homoptera: Aphididae) in the Laboratory. Biol Control 31(3):306-310

Lin QC, Chen H, Yin YY, Zhang SC, Yu Y, Zhuang QY, Zheng L, Zhai YF (2019) Effects of temperature on the development and predation of Aphidoletes aphidimyza (Rondani) larvae. Chinese J Appl Entomol 56(1):79-84

Livdahl TP, Stiven AE (1983) Statistical difficulties in the analysis of predator functional response data. Can Entomol 115:1365-1370

Luhring TM, Vavra JM, Cressler CE, DeLong JP (2019) Phenotypically plastic responses to predation risk are temperature dependent. Oecologia 191:709-719

McCoull CJ, Swain R, Barnes RW (1998) Effect of temperature on the functional response and components of attack rate in Naucoris congrex Stal (Hemiptera: Naucoridae). Aust J Entomol 37:323-327

Murdoch WW (1983) The functional response of predators. J Appl Ecol 10:335342

Sarnevesht M, Gheibi M, Hesami S, Zohdi H (2018) Predation by Anthocoris minki pistaciae Wagner (Hemiptera: Anthocoridae) on Agonoscena pistaciae Burckhardt and Lauterer (Hemiptera: Psyllidae) at different temperatures. Egypt J Biol Pest Control 28:76

Schwarz T, Frank T (2019) Aphid feeding by lady beetles: higher consumption at higher temperature. BioControl 64(3):323-332 
Sluss RR (1967) Population dynamics of the walnut aphid, Chromaphis juglandicola (KALT.) in Northern California. Ecology 48(1):41-58

Su M, Tan XM, Yang QM, Wan FH, Zhou HX (2018) Temperature adaptability of two clades of Aphelinus mali (Hymenoptera: Aphelinidae) in China. Egypt J Biol Pest Control 28:16

Symondson WO, Sunderland KD, Greenstone MH (2002) Can generalist predators be effective biocontrol agents? Annu Rev Entomol 47(1):561-594

Wani SA, Ahmad ST (2014a) Competition and niche-partitioning in two species of walnut aphids. Int I Sci Res Rev 3(2):120-125

Wani SA, Ahmad ST (2014b) Interactions between species in walnut orchard ecosystem of Kashmir Valley, India. Int J Pure and Appl Zool 2(2):200-204

Watt KEF (1959) A mathematical model for the effect of densities of attacked and attacking species on the number attacked. Can Entomol 91:129-144

Xing HC, Lu ZZ, Zhao L, Zhan X, Gao GZ, Luo ZH (2018) Potential risks of duskyveined walnut aphid, Panaphis juglandis (Goeze) ( Hemiptera: Aphididae) in China. J Environ Entomol 40(4):769-774

Zamani AA, Talebi AA, Fathipour Y, Baniameri V (2006) Temperature-dependent functional response of two aphid parasitoids, Aphidius colemani and Aphidius matricariae (Hymenoptera: Aphidiidae), on the cotton aphid. J Pest Sci 79: 183-188

\section{Publisher's Note}

Springer Nature remains neutral with regard to jurisdictional claims in published maps and institutional affiliations.

\section{Submit your manuscript to a SpringerOpen ${ }^{\circ}$ journal and benefit from:}

- Convenient online submission

- Rigorous peer review

- Open access: articles freely available online

High visibility within the field

- Retaining the copyright to your article

Submit your next manuscript at $\boldsymbol{\nabla}$ springeropen.com 